\title{
Don't Wait Until You Get Whacked on the Knees: An Appreciation for Reflexive Management
}

\author{
David L. Corsun \\ Cornell University \\ Cathy Enz \\ Cornell University
}

An interesting question was recently posed by a guest speaker to undergraduate students in a strategic management course: "If you saw trash on the floor of your student cafeteria and lounge, would you bend down to pick it up? If you don't see the trash now, why should I trust that you will begin to see it when it is in my hotel cafeteria or lobby?"

When do managers develop the radar necessary to see the small details of hotel operations management? Why do some managers see what others do not even seem to recognize? What is seen reflects a manager's and an organization's values. Philip Mirvis (1992) argued that "what leaders choose to attend to...is to some degree a function of their worldviews and the assumptions they hold about human nature" (pp. 59-60). Mirvis stated further that what is required is "an enriched view of human nature to see perceptively into people, gain their confidence, and rally them...." (pp. 59-60). Willis Harman (1990) reminded us that "in order for corporations to attract and hold the most creative people (and hence to compete in the national and global markets) they have to become cooperative and caring systems, in which appreciative relationships are based on shared meaningful activity" (pp. 5254). While at first blush the trash example may not seem meaningful or demonstrate human caring, there are many layers of meaning beneath one's actions. Managers and employees send and receive behaviors as signals of relationship and respect, of caring, appreciation, and cooperation.

Some might dispute that seeing a relationship between people and trash constitutes managerial radar. In their eyes, this relationship does not even exist. For many of these managers, radar is numerical. If something does not appear on a budget, a balance sheet, or an income statement, they miss it. Still others, gifted problem solvers, might see radar as the ability to distinguish between problems and symptoms, between facts and viewpoints. We agree that these are types of radar, but not complete. Managerial radar is not just seeing the underlying "what." The caring component of radar is the "how" - the process-radar-ofmanagement conveys the importance of the person whose job it is to pick up trash by bending down and picking it up and not waiting for that person to do it. 
The trash example points to two managerial diseases. One is the "disease of me." The manager whose ego is inflated such that he or she is self-oriented rather than team-oriented is afflicted with the disease of me. Ironically, in the short term, the afflicted manager is not necessarily the sufferer. The employees who work with the diseased suffer. They are given the message that they are not valued, respected, or empathized with. Their reactions to work are likely to reflect this. In short, people tend to respond to hostility with hostility, and kindness with kindness. A well-developed tit-for-tat relationship means that a manager with an overblown ego is likely to be both an insidious and invidious presence. He or she points to the trash but does not bother to bend down to pick it up. Such a manager's relatively inconspicuous action has a reciprocal and harmful effect because it creates resentment among employees.

The second disease indicated by the invisibility of trash is tunnel vision or poor managerial vision. Good managerial vision is peripheral and enables one to distinguish between information and conjecture, between problems and their manifestations. Managers with good vision use a wide-angle lens to see beneath and beyond the readily evident. A focused peripheral view provides context for the tunnel. Without contextual understanding there is no relationship between people and trash. Those who are unable or unwilling to see broadly are also injurious to the organization and its members. Their hospitality is flat and lifeless because they extend it only to those who pay for it. Peripheral vision pulls employees into the frame and reminds managers to be gracious, warm, cordial, and considerate of employees as well. To act otherwise is to deny employees their dignity and cultivate a negative, tit-for-tat, reactive work environment.

Managers are fond of sharing operational war stories. This practice serves to socialize young managers to believe that accolades and renown go to the one who is best at putting out fires. Inculcating young managers with this perspective has negative consequences tor organizations. Glorifying reactivity hinders proactivity and causes many of the fires in the first place. Managerial tunnel vision prevents one from anticipating and avoiding problems. Managers with poor vision are reflexive in the medical sense; their reactions are knee-jerk. These managers spend much of their time putting out fires, most of which they light themselves. Like the effect of overlooked trash on the floor, distrust, disregard, arrogance, superiority, and insensitivity are incendiary but preventable.

\section{Caring Managerial Radar}

Managers must constantly be attentive to people and things in their environment. Like some of the students in the classroom mentioned earlier, some managers have never fully understood the need for the radar that allows one to see the trash and thee pick it up, to place oneself in the role of employee. Whether consciously or not, some managers who begin their careers actively "sweeping" the environment allow their radar to fall into a state of disrepair or atrophy. Managers who have effective radar detect, observe, and probe deeply. They not only sense presence, they have "presence." The presence makes them visionary. Effective managerial radar helps one project a sense of ease, poise, or self-assurance" that employees 
respond to with respect (Stein \& Urdang, 1967). Hospitality that is offered without a price attached is returned; kindness is repaid with kindness and dignity is repaid with loyalty.

What is this managerial radar and what does it look like? Probably the best way to illustrate this concept is to use $M^{*} A^{*} S^{*} H^{\prime} s$ Walter "Radar" O'Reilly as an example. O'Reilly was the corporal who acted as the administrative assistant to Colonel Blake. Because he saw beyond and beneath the obvious, Radar O'Reilly anticipated the needs of those around him. He acted to prevent fires, not to commit arson. Radar's focus was the team, the person, the vision, not the self:

Col. Blake: "Radar."

Radar: "Yes sir."

Col. Blake: "Get...."

Radar: "I'll get a hold of Major Burns...."

Col. Blake: "....a hold of Major...."

Radar: "....I'll tell him to put...."

Col Blake: "....Burns. Tell him to hold...."

Radar: "....a couple of surgeons from...."

Col Blake: "....a couple of surgeons...."

Radar: "....the day shift to...."

Col Blake: "....from the day shift...."

Radar: "....the night shift."

Col Blake: "....to the night shift."

(Preminter, I. (Producer), M*A*S*H (film))

Working without a functioning radar system is a disease that, if untreated, can cripple a business and do irreparable damage to one's career. Not understanding why the simple act of picking up paper off the floor is important can prevent a manager from ever developing the feeling and observational skills good management requires. Young managers especially must understand the need for radar, but often do not. Some middle level managers once understood this need but forgot to keep understanding. Finally, some managers who have attained positions of considerable status and responsibility feel entitled to delegate their radar and hence no longer need to understand or care anymore (the disease of me).

Effective managerial radar "detects" more than presence, it probes deeply to "find out the true character or activity of" someone or something (Stein \& Urdang, 1967). Managers with caring, focused radar, recognize that by picking up the trash off of the floor themselves signals to employees how much they value employees and their tasks. Managers who learn to probe deeply develop empathy and recognize that those who perform in-line positions are people, not positions. Managers who assume that employees will retrieve what they themselves step over effectively say "I expect you to do what I will not. You and the task are beneath me." The message, and it is one that spreads like cancer, is that managers who do not pick up trash do 
not hold the employees who are expected to pick up trash in very high regard. How is the employee to preserve his or her dignity under such circumstances?

Deep probing of the environment requires that managers employ the social definitions of reflexiveness, contemplation, and introspection. Reflection helps ensure that people-valuing radar gets honed rather than atrophied. The thinking, pondering, and meditating that social reflexiveness implies enables proactivity and fire prevention. Reflexiveness maintains accuracy of memory and proper perspective. Managers who do not appreciate the difference between person and position or who value neither send the message that people are unimportant. These managers respond to the absence of earned respect by trying to manage, or command, respect. The old management models that preach control, direct, and order, ignore the elements of exchange and reciprocity in respect and trust. Without respect and empathy for the people and their positions, adherence to the old models fails to produce positive results in today's workplace. When a manager communicates that washing pots, mopping the floor, and other such tasks are jobs he or she would never perform, the employees who have those jobs don't want to either. Managers who do not reflect, deflect. They turn their organizations aside from a true course in which people are valued.

Deeply probing, effective managerial radar is analogous to the detection and observance skills great stage and screen actors possess. The sense of awareness and control great actors feel makes them convincing and gives them presence.

\section{Management as Theater}

The theatrical metaphor helps illustrate the difference between the old command and control management model and the reflexive model. According to the command and control model, management views itself as producer-director. Managers bear responsibility for the whole production - scenery, lighting, repairs and maintenance, marketing and sales, wages and benefits, and even teaching the actors the nuances of their roles. Almost exclusively, the actors - the front line employees - interact with the guests, and much of this interaction is scripted by management. The producer-directors act as though the guests are not privy to what happens backstage or during rehearsal.

Closer to the workplace theater is the manager as actor-director. In this scenario, the director is on stage. He or she crafts the setting, makes sure everyone knows the roles, always acts as him or herself, and allows the action to unfold. The action that ensues does not take place out of earshot, during rehearsal, when only the cast is present. In this play all the improvised activity, including the issuance of stage directions, is public. Ultimately, everyone involved in the production of hospitality, including the consumer, is part of the cast. Hospitality is interactive theater and the manager is as much an actor as a producer. There is no backstage.

Improvisation teaches one to "use" everything. Improvisation is the training that enables actors to develop their theatrical radar. Actors require radar because, even in a scripted scene performed night after night, nothing happens exactly the same way twice. The 
audience demands that every facial tic, clearing of the throat, and trip over a rug be justified. When managers engage in behaviors that indicate they are thinking that they are only producing-directing or only backstage, they overlook the impact of their actions on their scene partners, staff, and peers. Waiters, reservationists, and guest service agents react to the cues provided by their managers. In turn, the clientele react to the cues provided by the front line employees.

Extending the theatrical metaphor one step further makes it somewhat unnerving. The guest plays more than one role. The guest is also the reviewer. Every scene, each exchange between actors, gets reviewed. These reviews become part of the performance in that they shape action into the future. If critical enough, they should serve as a catalyst for rescripting or recasting the show. Regrettably, the guest reviewer may simply skip future performances and go to another business to experience its play.

Each of us enacts multiple roles daily. One's role repertoire may include sister, mother, lover, daughter, artist, and front desk shift supervisor. Separating person from position becomes simpler when one recognizes that although it may dominate while working, one's work role may not dominate one's life. The manager who automatically defines employees by their work roles doesn't use his or her radar. Probing beneath the position, past employees' job titles, reveals how they define themselves. A little reflection can help managers remember how frustrating it can be to be narrowly or misdefined by others.

Reflexivity forces managers out of their producer- director boxes. Thinking and understanding, listening to the cues of employee actors, engenders actions borne of relationships. A good scene partner is one who is interested in making his or her partner look good. When everyone in the scene subordinates his or her own needs to the others' needs, they all look like great actors. The result is a seamless, flawless piece of work. In the context of hospitality, the result is interactive theater that is consistently well reviewed. In summary, reflexivity can engender tit-for-tat relationships between managers and employees in which kindness, respect, and loyalty are traded, and dignity is preserved. How better to provide hospitality to all?

\section{How Do You Get from Knowing to Understanding?}

In our discussions with managers and hospitality students, we are struck by the paradoxical relationship between knowing how important this radar based on trust and respect is and understanding how to use it. Some have performed the line level tasks and refined the radar. These people have finely tuned, sensitive radar. Others have also done this work, yet they haven't developed their appreciation radar. The situation is further complicated by those whose experiences do not include any line level work. Among this group there is also a split between those who have appreciative radar and those who do not.

Is the difference between the trash picker-uppers and their walk-by peers innate or environmental? The picker-uppers are empathic. This spirit embodies caring, understanding, 
trust, and respect. Empathy and reflexiveness are complementary. How radical a change is required for an individual to become empathic? Fortunately, the change is not as pronounced as one might initially think. Part of the human experience is the surprise we feel when we encounter the familiar in an entirely new way. Something you may have done or seen before can change completely if you do or look again after taking a step off center. The world and the people in it look different when viewed from a different angle, from a new perspective.

At the flagship property of a large upscale hotel chain, management instituted what they call the 10- foot rule. Regardless of your position, if you pass within 10 feet of a guest or another employee, you must establish eye contact and greet the person. The general manager at this property understands and is reflexive. He influenced people and created an environment in which people are more important than positions. His reward is a staff that works hard and works well. His property consistently outperforms its peer properties in customer service and satisfaction.

Another senior manager of a restaurant chain visits and meets in focus groups with store-level employees on a regular 8-week cycle to talk with them and listen. Store managers' compensation is' tied to these employees' satisfaction, but more powerful than that, the corporate executive is conveying care, respect, and team spirit. The chain has employee turnover levels that are one third of the industry norm.

Move your managers. Train them to accept, not block. Coach them to be good actors and thus better scene partners. Help them to raise the sensitivity level of their radar until it is finely tuned. Encourage your peers, your boss, the people who report to you, in short, all the actors you perform with, to reflect and to actively develop highly sensitive, complete radar. You can do so in several ways.

Advocate or provide improvisational theater training, it develops radar. Train in organizational skills and time management. Without the time to be proactive, managers will continue to be both firestarters and extinguishers. Be an exemple for your managers. Model reflexive management in your own work. Be certain the management behaviors you reward are consistent with the behaviors you ask for. For example, if you expect proactive behavior, yet demand that your managers staff at skeletal levels when they are in the property, you are the firestarter. Forcing your front office manager to spend his or her days putting out fires at the front desk limits his or her ability to be sensitive and proactive. If you want social reflexiveness, don't paint your managers into a reactive corner.

Learning reflexiveness is not automatic and does not magically occur. It must be taught, encouraged, and rewarded to take hold in an organization. It must be designed into your operating system. Reflexiveness must become part of your organization's culture for it to be embraced. Learning not to knee- jerk gets easier when others practice reflexiveness. It is easier to be a good actor if others are good too. 


\section{What is the Payoff?}

Presence is important for all employees' selfesteem and dignity. Letting people know that they and their work are valued and respected will engender trust and respect. Recall that trust and respect are reciprocal. Further, they are most often symmetric. Managers receive only as much as they give. All interactions are based on relationship. Getting work accomplished well through others is much more likely when the mar ager-employee relationship is not adversarial. The use of the term "scene partners" to describe actors working together is significant. Even when the characters are adversaries, the actors are partners. When one gets this feeling that management and staff are working at cross purposes, "How did we get here?" is an appropriate question to ask. Jammed or atrophied radar is likely to be a significant part of the answer.

Empathic listening and keen observation require focus. Empathic listening is based on relationship -here is one place trust and respect come into play. Hearing and truly understanding are not always the same. Watch carefully. It is not enough to just look, one must also notice. Managers who are not observant, who look but do not see, miss valuable cues. The more cues one misses, the worse the performance. Successful management is not about ego. Success comes from making employees look good. Curing the ego disease begins with a redefinition of success driven by valuing people.

Reflexive managers, then, listen empathically. They observe and notice. Appreciating the value of the people, the positions, and how the two are intertwined, reflexive managers are able to relate to their employees as people first. The payoff is mutual trust and respect that result in great performance.

Managers are not just producers and directors. They are also actors in a play in which every line, whether spoken onstage or backstage, matters a great deal. As a consequence, every actor matters. The producer-director is no more important in the eyes of the reviewer than any of the other players. Lousy I reviews close shows early, usually before they have paid a return on the investment made to get the theater doors open. Ultimately, then, the reviews are all that matter. Reflect on that the next time you make eye contact with an employee.

\section{References}

Harman, W. W. (1990). Shifting context for executive behavior: Signs of change and revaluation. In S. Srivastva, D. L. Cooperrider, \& Associates (Eds.), Appreciative management and leadership (pp. 37-54). Jossey-Bass: New York.

Mirvis, P. H. (1990). Merging of Heart and Mind in Crisis Management. In Srivastva, S., Cooperrider, D. L., \& Associates (Eds.), Appreciative management and leadership (pp 5590] Jossey-Bass: New York.

Stein, J., Urdang, L. (1967) (Eds.). Random House dictionary of the English language. Random House: New York. 
Preminter, I. (Producer), Altman, R. (Director) year $M^{*} A^{*} S^{*} H$ (film). Los Angeles: 20th Century Fox. 